\title{
Investigations of potsherds of miniature cups and household pots from the first millennium AD (the case study on the Western Lithuanian ceramics)
}

\author{
Raimondas Giraitis ${ }^{1 *}$, \\ Audronè Bliujiené , \\ Aušra Selskienè ${ }^{1}$, \\ Vidas Pakštas ${ }^{1}$ \\ ${ }^{1}$ Institute of Chemistry, \\ Center for Physical Sciences and Technology, \\ 3 Sauletekio Avenue, \\ 10257 Vilnius, Lithuania \\ ${ }^{2}$ Institute of Baltic Region History \\ and Archaeology, \\ Klaipéda University \\ 84 Herkaus Manto Street, \\ 92294 Klaipeda, Lithuania
}

\begin{abstract}
This article presents data on the structure and elemental composition of hand-built miniature cups with a smooth surface, that were enclosed into burials as funeral pottery, and household pots dated to the first millennium AD found in four different archaeological sites of Western Lithuania. Investigated funeral and household pottery samples reflect the chemical composition of the local raw materials used for their production, while the variations in composition point to different clay locations, as well as use of distinct tempers and peculiarities of ceramics firing technology.
\end{abstract}

Keywords: archaeological ceramics, elemental composition, funeral miniature cups, household pots

\section{INDTRODUCTION}

In the archaeology, potsherds of broken pots make the largest part of the artefacts discovered in settlement cultural layers. During the first millennium $\mathrm{AD}$, hand-built pots and cups in different sizes for various purposes were produced. Plenty of other different artefacts produced from clay were widely used by societies in their daily life, for example, spindle whorls used for spinning threads. Likewise, loom weights to weave textile were also produced from clay. Crucibles, casting moulds and scoops for metal smelt were manu-

\footnotetext{
*Corresponding author. Email: raimondas.giraitis@ftmc.lt
}

factured from clay, as well. However, the composition of the clay paste from which these artefacts were made in the first millennium $\mathrm{AD}$ and the technological peculiarities of the ceramics have not been adequately studied in Lithuania [1] 4. The article presents the results of the investigations of potsherds from four settlements in Western Lithuania and the Lower Nemunas region (Opstainiai-Vilkyškiai, Lazdininkai-Kalnalaukis and Imbarè) and two burial grounds (Užpelkiai and Lazdininkai-Kalnalaukis). Altogether 10 ceramics samples characteristic of different periods of the first millennium were investigated (Table 1).

One of the aims of our research was to confirm or deny the assumption that the technologies used 
Table 1. Description of the archaeological sherds

\begin{tabular}{|c|c|c|c|c|c|c|}
\hline Site & Circumstances of discovery & $\begin{array}{l}\text { Sherd } \\
\text { ID }\end{array}$ & $\begin{array}{l}\text { Length', } \\
\text { mm }\end{array}$ & $\begin{array}{l}\text { Width' } \\
\text { mm }\end{array}$ & $\begin{array}{l}\text { Thickness }{ }^{3}, \\
\text { mm }\end{array}$ & $\begin{array}{l}\text { Weight, } \\
\quad \mathrm{g}\end{array}$ \\
\hline \multirow{3}{*}{ Užpelkiai cemetery } & Trench XVI, sq. B16, depth $40 \mathrm{~cm}$ & U1 & 37 & 32 & $5.2-10.1$ & 10.10 \\
\hline & Trench XIV, sq. A5, depth $82 \mathrm{~cm}$ & U2 & 44 & 38 & $5.0-8.5$ & 11.65 \\
\hline & Trench XX, sq. B9, depth $42 \mathrm{~cm}$ & U3 & 53.5 & 43.5 & $9.4-12.3$ & 32.32 \\
\hline \multirow{3}{*}{$\begin{array}{l}\text { Opstainiai-Vilkyškiai } \\
\text { hillfort, foot settlement }\end{array}$} & $\begin{array}{l}\text { Trench 3, pit no. 1, depth } \\
\text { 70-100 cm }\end{array}$ & V1 & 62 & 43 & $9.2-13.6$ & 28.50 \\
\hline & Trench 3, pit no. 1, depth & V2-1 & 39 & 31 & $6.6-9.6$ & 10.52 \\
\hline & $70-100 \mathrm{~cm}$ & V2-2 & 33.5 & 22 & $5.0-9.0$ & 6.66 \\
\hline $\begin{array}{c}\text { Lazdininkai-Kalnalaukis } \\
\text { settlement }\end{array}$ & Trench 7, pit no. 37, depth $86 \mathrm{~cm}$ & L1 & 33 & 18 & $5.5-10.0$ & 4.92 \\
\hline \multirow{2}{*}{$\begin{array}{l}\text { Lazdininkai-Kalnalaukis } \\
\text { cemetery }\end{array}$} & \multirow{2}{*}{ Grave 64/1976 } & L2-1 & 32 & 24.5 & $2.1-9.7$ & 6.63 \\
\hline & & $\mathrm{L} 2-2$ & 32 & 21 & $2.2-6.7$ & 2.62 \\
\hline $\begin{array}{l}\text { Imbarè hillfort, } \\
\text { foot settlement }\end{array}$ & Stray find & I1 & 74 & 59 & $7.0-12.0$ & 64.74 \\
\hline
\end{tabular}

Note: 1 - in the longest part, 2 - in the widest part, 3 - minimum-maximum.

for the manufacturing of the household pottery and the funeral miniature cups differed, which means that the miniature cups were made of clay paste of different composition and were 'worse' fired, as well as to determine possible differences in clay and temper composition between the samples of ceramics used for different purposes.

\section{CHARACTERIZATION OF THE POTSHERDS}

The Užpelkiai (Municipality of Kretinga District $\left.\mathrm{N} 55^{\circ} 56^{\prime} 17^{\prime \prime}, \mathrm{E} 21^{\circ} 7^{\prime} 59^{\prime \prime}\right)$ burial ground and the surrounding settlement make one archaeological complex, located on the left bank of the Žiba River on a low sandy hill that is clearly distinguished among swampy meadows (Fig. 1). In the burial ground 107 human inhumations and one cremation have been investigated. The first burials here are dated to the beginning of the 3rd century and the burial ground was continuously used till the end of the 12th century AD. Miniature cups were found in $30 \%$ of burials dated to the 3rd century - the middle of the 5th century; moreover, some of the potsherds of miniature cups were found accidentally, that is, they came from disturbed burials. Miniature cups, merely $5-13 \mathrm{~cm}$ in height, are typical burial artefacts that might be dated from the 3rd century to the middle of the 5th century AD in the Western Lithuania's burial grounds. Miniature cups were placed in male, female or children burials, usually in the head area.

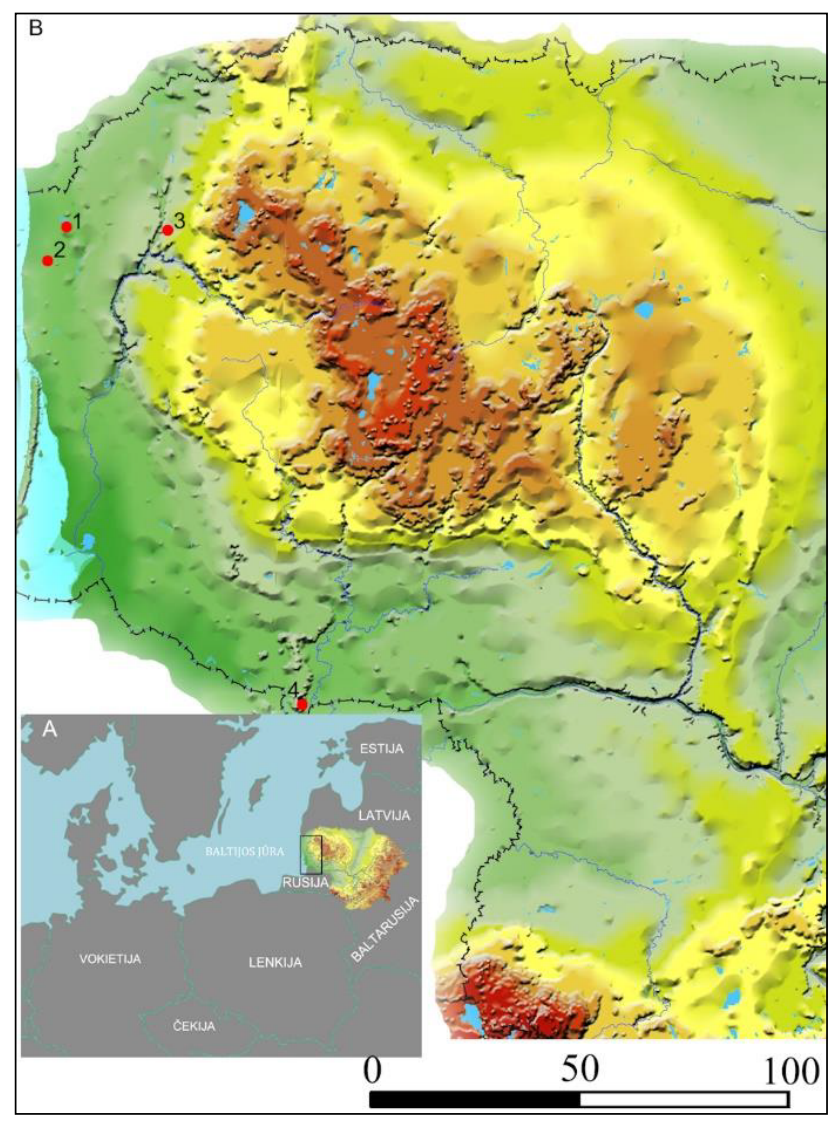

Fig. 1. North-Eastern Europe and Lithuania (A). Studied areas in Western Lithuania with the location of investigated sites: LazdininkaiKalnalaukis (1); Užpelkiai (2); Imbarė (3); Obstainiai-Vilkyškiai (4)

The investigated potsherds belonging to Užpelkiai were parts of three hand-built miniature cups with a smooth surface. Potsherd U1 is 
a bottom part of a miniature cup with a smooth surface (Fig. 2) [5, 6. It is of irregular shape, slightly convex. The outer (convex) side is mottled - dark brown (almost black) with brown spots. The darker areas are bright, likely due to the polymer used and, in part, due to surface treatment, in order to strengthen the potsherd during research, while brighter areas are rougher and sandy. The inner (concave) side is also mottled, but of dark greyyellowish brown colour, matte, very smooth. One large, bright insert and several very small inclusions are visible on the inner surface. Lamination can be observed from the side. The outer surface of the potsherd is crumblier compared to the inside surface.

Potsherd U2 is a fragment of the orifice and neck of a miniature ' $S$ ' shape profile cup. It is of irregular convex form, brown in colour, however, the outer surface is lighter as compared to the inner one. The inner surface is bright. The outer surface is rather even, but finely rough, because the surface is crumbled, affected by the ceramics erosion process. The inner surface is somewhat smoother compared to the outer one, but nevertheless it is rather rough. The sides of the potsherd are uneven, fine pebbles appear in view on their surface.

The third potsherd found at the Užpelkiai burial ground (U3) was also a small bottom fragment of a hand-built miniature cup with a smooth surface, therefore it was thicker compared to U2 [6, 月] (Fig. 2, Table 1). Potsherd U3 is of irregular shape, convex. The outer surface is dark brown with bright darker spots. The inner surface is somewhat lighter compared to the outer one and mat. The outer surface is damaged in places, due to the ceramics erosion process the top surface elements are peeled off. The inner part of the potsherd is smooth, however, it is cracked in some places. Also, on the inner surface several fine and one coarse rock insertions can be seen. On both the potsherd surfaces there are adhered fibres, which can be the remains of grown in plant roots.

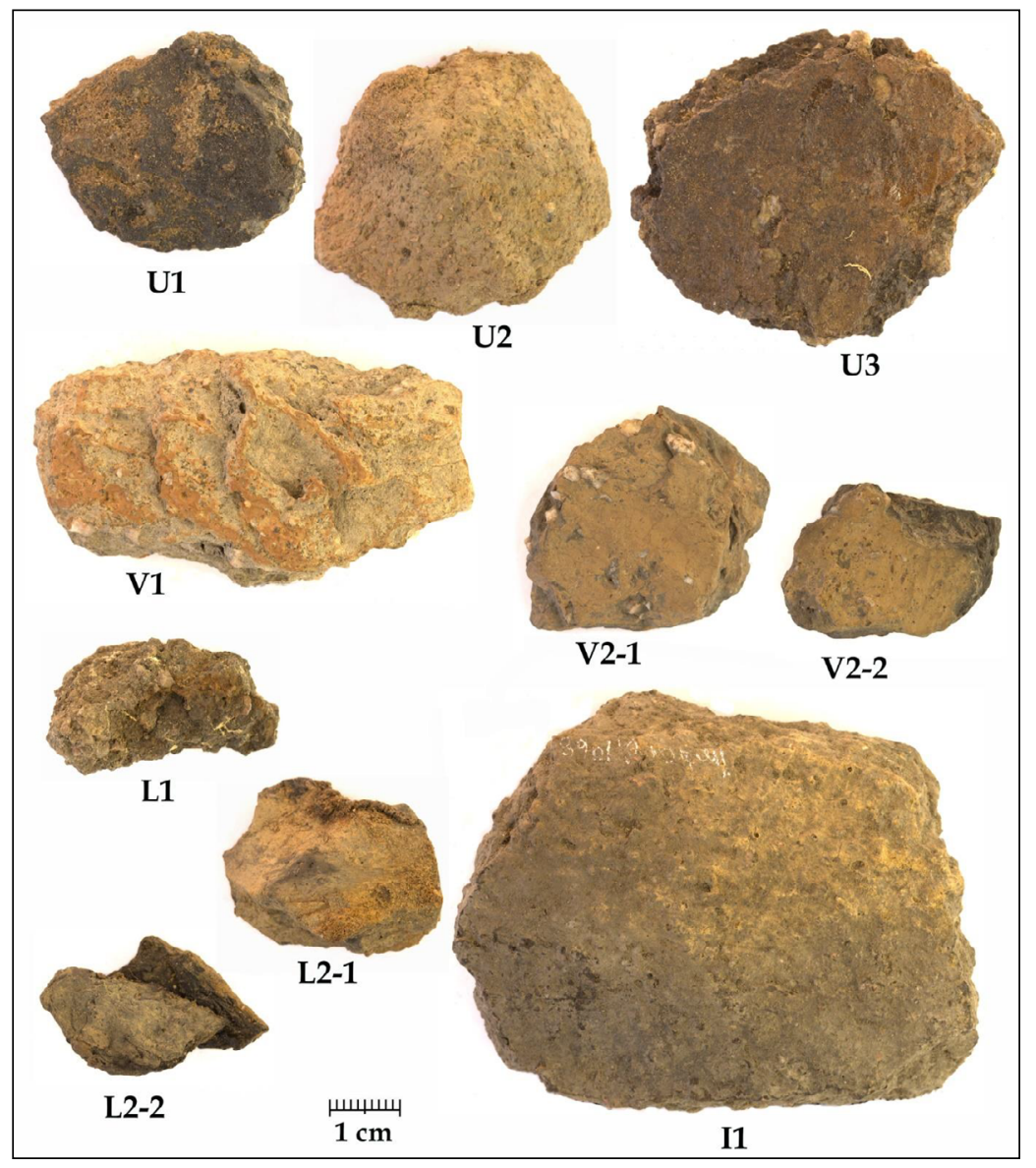

Fig. 2. Images of the investigated potsherds from archaeological sites: Užpelkiai cemetery (U); Obstaniai-Vilkyškiai hillfort foot settlement (V); Lazdininkai-Kalnalaukis cemetery and settlement $(\mathrm{L})$; Imbare hillfort foot settlement (I) 
The Opstainiai-Vilkyškiai hillfort with a foot

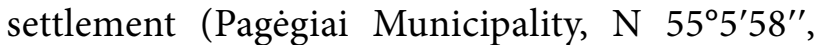
$\mathrm{E} 22^{\circ} 7^{\prime} 33^{\prime \prime}$ ) is located on the cape of the highlands on the left bank of the Apsta River. The hillfort was surrounded by the foothill settlement (Fig. 1) [8]. The potsherds were found in the cultural layer of the foot settlement (Fig. 2, Table 1) [9, 10]. On the basis of the studies of the food residue detected on the inner rough surface (also called scaly surface) of the hand-built household pot, we were able to determine that the pottery belongs to the 336-543 $\mathrm{AD}$ according to AMS ${ }^{14} \mathrm{C}$ dating $(2 \sigma$ probability is $95.4 \%$ ) [11]. Potsherd V1 belongs to this kind of rough pottery, and is oblong in shape, slightly convex. Its outer surface is very uneven, relief decorated (rough), light brown, almost grey, with outward-projecting places of reddish-brown colour. The inner surface is smooth, of light brown colour with yellowish and grey spots. The potsherd sides are uneven and crumbled.

With reference to the settlements in Western Lithuania, the studied hand-built potsherds with a smooth surface (V2-1 and V2-2) can be dated to the 9th-11th centuries [12] (Fig. 2). Potsherd V2-1 is of convex shape, its outer surface is light brown, angled pieces of rock can be seen on its surface, the presence of which indicates that the clay paste had shrunk strongly when drying. The inner surface is somewhat darker (with a grey stripe). Potsherd V2-2 is also of convex shape; its outer surface is light brown. The inner surface is much darker, of a dark grey colour, but its surface is smoother as compared to that of potsherd V2-1.

The Lazdininkai-Kalnalaukis (Municipality of Kretinga District (N 56 $0^{\circ} 45^{\prime \prime}$, E $\left.21^{\circ} 12^{\prime} 16^{\prime \prime}\right)$ ) burial ground and settlement are in a lowland area on the seaside plain between the left bank of the Darba River and the right bank of the Lazdupis stream, currently drained (Fig. 1). 521 burials were investigated. In the northern part of the burial site, beneath burials a destroyed settlement culture layer was found with postholes, fireplaces, pits of various purpose, stone structures, clay plaster used to plaster over outer house walls and iron slag from bloomers, indicative of iron production in the settlement, and other archaeological finds. The above-mentioned cultural layer was disturbed at the end of the 1st century AD, when the burial ground was established. The investigated potsherd (L1) is a fragment of a large, handbuilt household pot with a rough surface found in the settlement, apparently in a sunken building [13]. Based on AMS ${ }^{14} \mathrm{C}$ dating of food residues found on the inner surface of this household pot, the vessel belongs to the $345-535 \mathrm{AD}$ ( $2 \sigma$ probability is $95.4 \%$ ) [11]. Potsherd L1 is only slightly convex, its outer surface is brown, while there is grey staining on the inner (concave) surface (Fig. 2).

Potsherds L2-1 and L2-2 are fragments of a miniature cup, found in burial 64 of a cremated male burial (Fig. 2) [14]. Potsherd L2-1 is of an irregular form, convex. Its outer surface is of a ginger colour with grey spots, also very thin fibres adhered to the surface can be seen. The inner surface is uneven, grey with yellowish-reddish spots. Potsherd L2-2 is of an irregular form, 'S' shaped, only slightly convex. The outer surface is brown, rather bright, while the inner surface is light grey, it is cracked in some places and a bright dark grey layer can be viewed. The potsherd seems to consist of two glued parts (Fig. 2).

The complex of the Imbare hillfort with a settlement (Municipality of Kretinga District, $\mathrm{N} 56^{\circ} 0134.2^{\prime \prime}$, E $21^{\circ} 3321.2^{\prime \prime}$ ) is located the left bank of Salantas and on the horn of the highlands on the right bank of the confluence of the Pilsupis River (Fig. 1). The foot settlement is located on the highlands of the left bank of the Pilsupis River [15]. A potsherd of a hand-built household pot with a finely rough surface (I1), which was found in 1968 in the cultural layer during the settlement field walk survey, was investigated. Potsherd I1 is irregularly shaped, hooded. The outer side is grey and yellowish-brown in colour. The inner side is darker, mottled - from light grey to almost black (Fig. 2).

The studies of archaeological ceramics revealed certain hand-built pottery peculiarities, such as surface treatment. It is obvious that there were attempts to polish the surface of the miniature cups, while the surface of the household pots was smoothed. Potsherds with a rough surface were also investigated.

\section{EXPERIMENTAL}

10 fragments of archaeological ceramics were examined. One would expect that all potsherds had been preserved (hardened) with polybutyl methacrylate (PBMA) or any other organic polymer.

Samples for TC, LOI and XRF analyses were milled with a ball mill 'Pulverisette 6' (FRITSCH, 
Germany) to $\leq 5 \mu \mathrm{m}$ sized particles and dried to a constant mass at $105^{\circ} \mathrm{C}$.

The total carbon (TC) content of archaeological ceramic samples was determined using a carbon and sulphur analyser ELTRA CS-2000 (Eltra $\mathrm{GmbH}$, Germany) according to the manufacturer's methodology.

The loss on ignition (LOI) was determined by heating the samples in a muffle furnace SNOL $8.2 / 1100$ (Umega, Lithuania) at $550^{\circ} \mathrm{C}$ for $4 \mathrm{~h}$, and at $1000^{\circ} \mathrm{C}$ for $2 \mathrm{~h}$.

For multi-element analysis of the ceramics samples an X-ray spectrometer with a wavelength dispersive detector Axios mAX (PANalytical, Netherlands) was used. $6 \mathrm{~g}$ of each sample was mixed with $1 \mathrm{~g}$ Hoechst wax $\mathrm{C}$ micro powder. The powder/binder mixtures were compressed into tablets $(\varnothing 37 \mathrm{~mm})$ using a hydraulic press applying the pressure of $150 \mathrm{kN} / \mathrm{cm}^{2}$ for $3 \mathrm{~min}$. The accuracy was determined using the external standards N 139 (Czech Republic), NCS DC60105 (China) and IMZ-267 (Poland). The paper presents the results of the main elements $(\mathrm{Si}, \mathrm{Al}, \mathrm{Fe}$, $\mathrm{Mg}, \mathrm{Ca}, \mathrm{Na}, \mathrm{K}, \mathrm{Mn}, \mathrm{P}, \mathrm{Ti}, \mathrm{Ba}, \mathrm{O}$ ) and trace elements (S, Ni, Co, Cu, Zn, Zr, Rb, Sr, Cr, Y, Pb, Cl). The relative standard deviations of measurements of two tablets were lower than $10 \%$.

Cross sections of archaeological ceramic samples were made at the predetermined locations us- ing a low speed cutter 'ISOMET' (Buehler, USA) with a diamond blade. The pieces of samples were dried in an electric drying oven at $105^{\circ} \mathrm{C}$ for $12 \mathrm{~h}$, mounted in epoxy resin under vacuum impregnation (CitoVac, Strues Inc.) and prepared using conventional techniques of grinding and mechanical polishing (Tegramin-25, Struers Inc.).

A Helios NanoLab 650 DualBeam workstation (FEI) was used for samples microstructure investigation. The elemental composition at different points of the polished samples was studied using an energy dispersive spectrometer with an Xmax $20 \mathrm{~mm}^{2}$ detector (Oxford Instruments).

\section{RESULTS AND DISCUSSION}

\section{Structure of the potsherds cross-sections}

The remains of archaeological ceramics found in the Užpelkiai burial ground differ not only in appearance, but also in the cross-sectional view (Fig. 3). The matrix of potsherd U2 is distinguished from the other potsherds investigated by its light red-brown colour and fine-grained temper (with the grain size up to $1.4 \mathrm{~mm}$ ) and narrow, short, multi-directional cracks forming a kind of net. Meanwhile, the matrix colour of potsherds U1 and U3 in cross-sections is dark brown, almost black. The matrix of potsherd $\mathrm{U} 3$ is distinguished from the other potsherds by very coarse, multi-dimensional

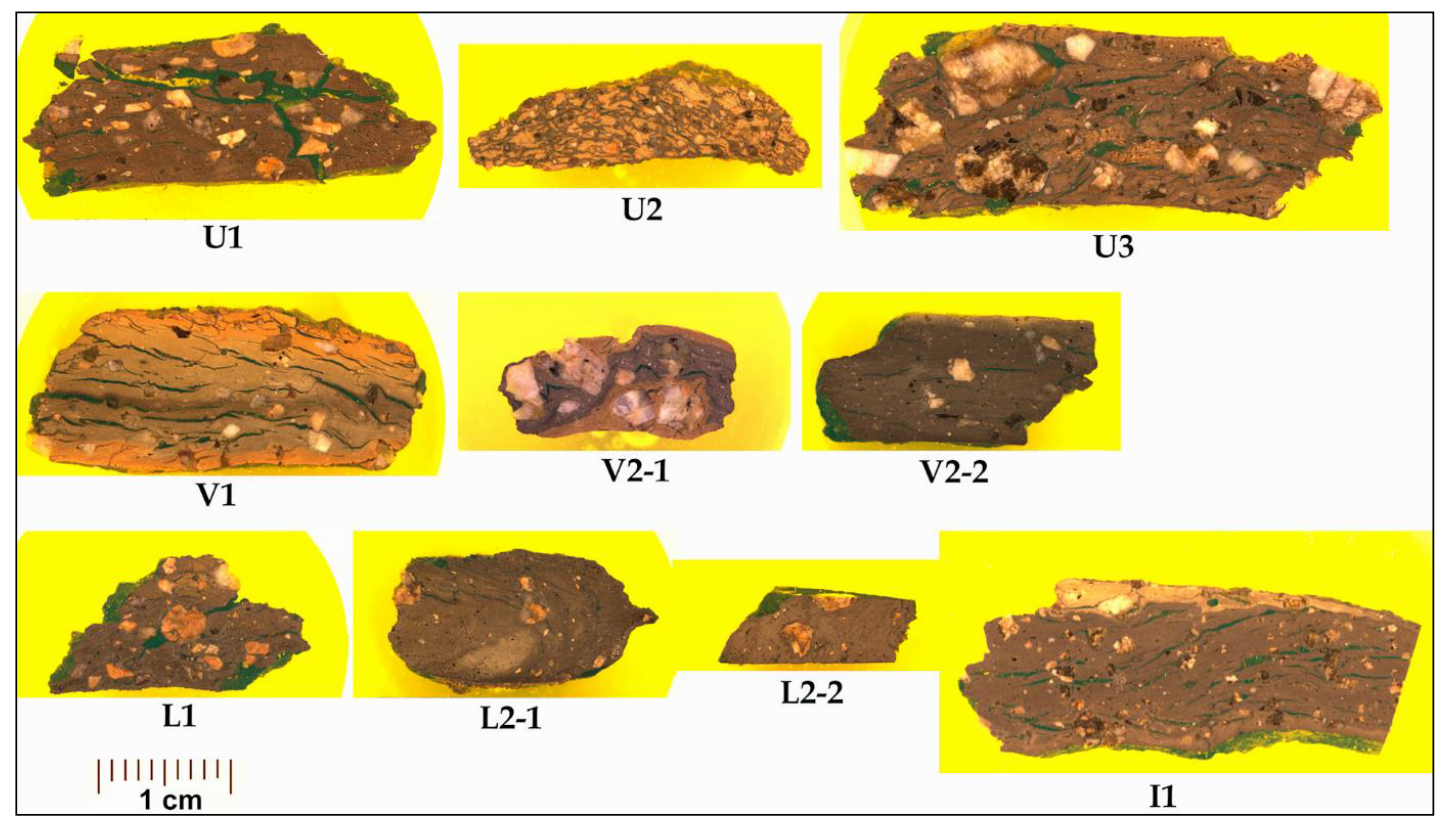

Fig. 3. Macroimages of cross-sections of archaeological sherds Užpelkiai cemetery (U); Obstaniai-Vilkyškiai hillfort foot settlement (V); Lazdininkai-Kalnalaukis cemetery and settlement (L); Imbare hillfort foot settlement (I) 
polymineral temper grains (grain size up to $8.8 \mathrm{~mm}$ ). There are many cracks in the cross-section of potsherds U1 and U3. The cracks have different lengths, widths and orientations. So, potsherd U1 is not durable because of large cracks.

The results of sample U2 examination suggest that the resin used in the preparation of the samples for EDX, when vacuuming, fills not only the cracks and other voids of the potsherd, but also penetrates into the porous ceramic matrix. This is clearly seen when comparing the views of the cross-sections of potsherd U2 (Fig. A) after cutting (A) and after resin filling and polishing (B). Photo A shows that the colour of the ceramic matrix is red-brown, and the penetration of the resin around the cracks and cracks in some part of matrix the colour darkens and becomes dark brown (B). The same effect can be expected in other potsherds, however, in the case of a dark ceramic matrix it will not be so clearly visible. Therefore, this should be taken into account when interpreting the data obtained. This effect was observed only due to the use of a resin with a fluorescent additive. In the photos, it is yellow, while large cracks are dark green, or fine cracks are dark brown.

The same effect, but not visible to the naked eye or an optical microscope, can be achieved by applying some other synthetic polymer resins, such as PBMA.

The cross-sections of the potsherds found in the Opstainiai-Vilkyškiai settlement are very different (Fig. 3). The colour of the matrix in the crosssection of sample V2-2 is dark brown, while the colour of the ceramic matrix of samples V1 and V2-1 is

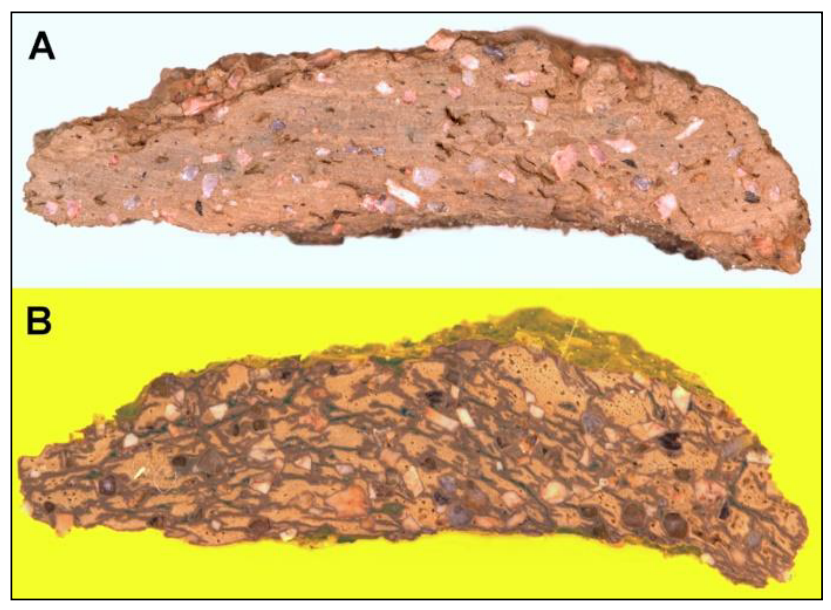

Fig. 4. Macroimages of the cross-sections of sherd U2: after cutting (A) and after resin filling and polishing (B) diverse - the colour of the matrix on the outer and inner surfaces is light red-brown, while the middle part is dark brown. It should also be noted that in the cross-section of sample V1 the colour change is fairly uniform from the outer surface to the centre, whereas a light-coloured band on the inner surface has a fairly clear boundary. In addition, on the inner surface of the potsherd there is a very narrow $(\sim 0.1 \mathrm{~mm})$ and very dense strip of even lighter colour, separated by small pores. The inner surface of the ceramic product is likely to have been slipped. The grain size and amount of the temper are also uneven in these ceramic matrices. Numerous extremely large (up to $4.8 \mathrm{~mm}$ in size) polymineral intrusions were detected in the matrix of sample V2-1. The size of temper grains in the matrix of sample V1 is similar to that of sample V2-2 (up to $2.4 \mathrm{~mm}$ ), but the quantity and distribution uniformity are different - in the ceramic matrix of sample V2-2 there are few grains and they are distributed uniformly.

The differences between the cross-sectional structures of potsherds V2-1 and V2-2 indicate that they are parts of different vessels and that these pots were produced using different firing technologies.

Although the appearance of potsherds L1, L2-1 and L2-2 found in the Lazdininkai burial ground differs, their cross-sections are of a very similar dark brown colour (Fig. 3). Only the grain size, quantity and distribution uniformity of the temper used differ. In the matrix of sample L1 there is a fairly large amount of uniformly distributed temper grains of different size (up to $3.5 \mathrm{~mm}$ ) and shape. Numerous cracks of different sizes can also be seen in the matrix. Meanwhile, the matrices of samples L2-1 and L2-2 are very similar not only in their colour, but also in their structure. The size of temper grains is also similar (up to $2.7 \mathrm{~mm}$ ) and temper grains are distributed very unevenly, the pores are of medium size and few in number. As for the differences, it is worth mentioning that in part of the matrix of sample L2-1 narrow, very long arc-shaped cracks can be seen, while there are no cracks in the matrix of sample L2-2. The matrix of potsherd I1 found in the Imbare settlement is quite dense, dark grey-brown, with a light brown strip on the outer surface that narrows and disappears completely (Fig. 3). This strip in its widest part $(2.8 \mathrm{~mm})$ has a fairly clear boundary, but the band becomes less pronounced as the strip narrows. The matrix has 
a fairly uniform distribution of a large amount of polymineral temper grains of a size up to $2.7 \mathrm{~mm}$. There are a lot of cracks, which differ in width and length, but they do not merge and of all the investigated ceramics, potsherd I1 was the strongest one.

The potsherds under investigation can be divided into three groups according to the cross-section colour:

- U2 - the potsherd colour is orange-brown throughout the whole cross-section surface;

- U1, U3, V2-2, L1, L2-1 and L2-2 - the potsherd colour throughout the whole cross-section surface is dark brown;

- V1, V2-1 and I1 - the potsherd colour is not uniform with a dark core and light margins.

The colour of the fired ceramics depends on its chemical and mineralogical composition, which in turn is determined by the composition of raw materials and the conditions of the combustion process (heating rate, maximum temperature and soaking time, redox environment, cooling rate, etc.) [16].

The red-brown ceramics colour is determined by hematite $\left(\alpha-\mathrm{Fe}_{2} \mathrm{O}_{3}\right)$, fine particles of which are spread in the ceramic matrix. The colour intensity and its shade may differ depending on the amount of hematite, the degree of crystallinity, shape and size of the particles [17]. Along with hematite, other iron compounds can be formed during firing of ceramics, and then the colour of the ceramics will depend on their quantitative relationship [18]. Ceramics of this type (such as U2) could only be obtained if the rate of temperature rise and especially the cooling rate was low, the maximum temperature was $>700^{\circ} \mathrm{C}$ and the soaking time was long enough [18].

Dark brown, dark grey, i.e. almost black pottery colour may be related to the formation of elemental carbon and/or iron $(+2)$ compounds (wustite, hercynite, etc.) in the ceramic matrix under a reducing environment or in the event of incomplete magnetite oxidation [19], under a slightly oxidising environment, insufficiently high temperature or short soaking time at the maximum temperature and rapid cooling, as magnetite oxidation no longer occurs at temperatures below $550^{\circ} \mathrm{C}$ [20].

The sandwich type structure when the crosssection edges of the potsherd are light and the core is dark may be formed in the presence of large amounts of organic compounds in the clay paste. In this case, the dark core remains even after ceramics firing in an oxidising environment at $800-850^{\circ} \mathrm{C}$ [21]. When firing in an open pit fire, vessels come in contact with flame and hot fuel, so the external gas environment is reducing or slightly oxidising. During such firing, the temperature rises very quickly, and the soaking time at maximum temperature is short. Once fuel is burned, rapid cooling starts to proceed. It is precisely during cooling that the surrounding gas becomes oxidising, but due to the rapid decrease in temperature, the oxidation of $\mathrm{Fe}(+2)$ compounds is interrupted. The rapid temperature dynamics during firing and the low thermal conductivity of the ceramic matrix can result in a temperature gradient between the walls of the potsherd and the interior [22].

\section{Chemical composition of the ceramic samples}

Loss on ignition (LOI) and total carbon (TC) content. LOI experimental data, i.e. the loss of sample mass after heating at $550^{\circ} \mathrm{C}$ for $4 \mathrm{~h}$ (LOI-550) and at $1000^{\circ} \mathrm{C}$ for $2 \mathrm{~h}$ (LOI-1000) and the total carbon content, are shown in Figs. 5 and 6 .

The mass loss of the dried sample within the temperature range of $20^{\circ} \mathrm{C}$ to $550^{\circ} \mathrm{C}$ is mainly due to the oxidation of organic compounds, including PBMA (polybutyl methacrylate used for the reinforcing of the upper layer of crumbling ceramics mass) [23]. Loss of the interlayer water of clay mineral, the dehydroxylation of amorphous metal hydroxides [24] and some minerals can also occur in this temperature range [25, 26].

As shown in Fig. 5, the total carbon content in the investigated potsherds correlates very well with the loss on ignition data at $550^{\circ} \mathrm{C}$ temperature:

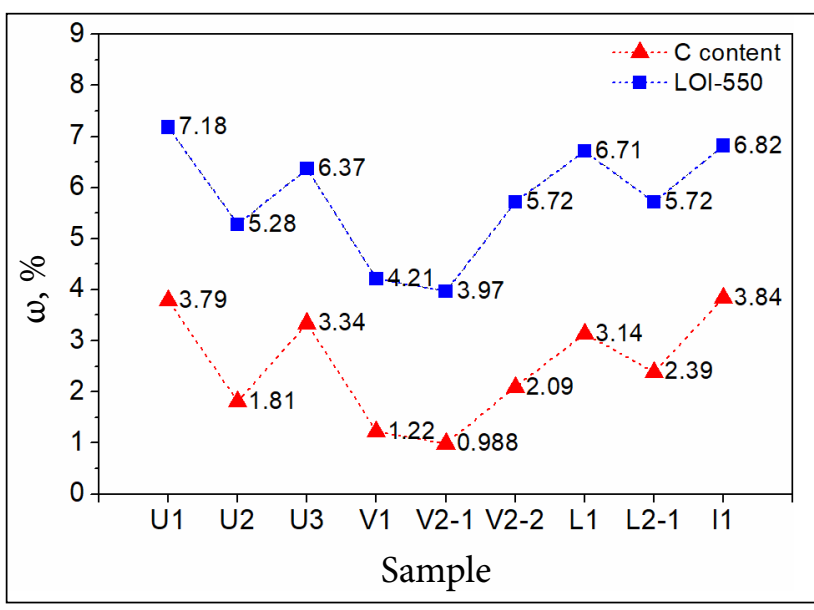

Fig. 5. LOI-550 and the total carbon content data of archaeological sherds, in weight $\%$ 


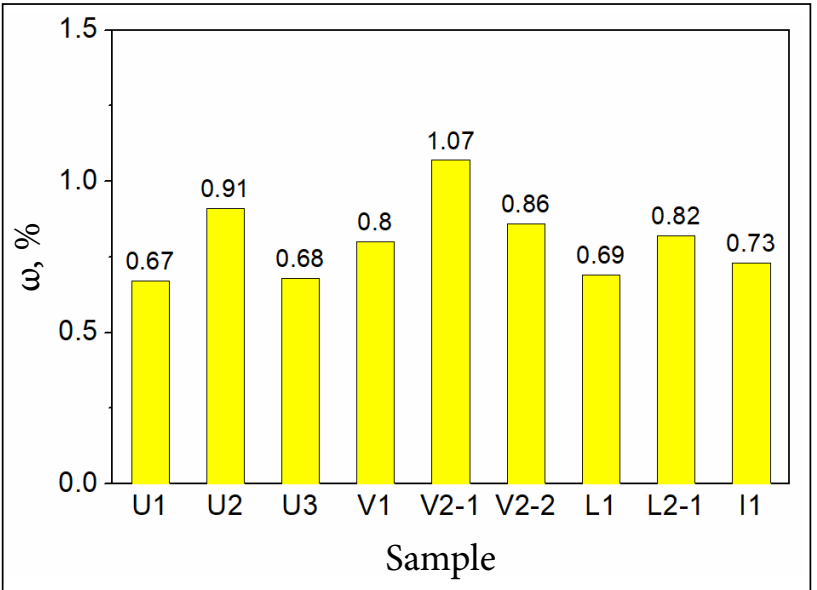

Fig. 6. LOI-1000 data of the archaeological sherds, in weight $\%$

the highest quantities of TC and LOI-550 were found in potsherds I1 (Imbarè) and U1 (Užpelkiai), and the smallest ones in potsherds V2-1 and V1 (Opstainiai-Vilkyškiai). These data confirm an assumption that all potsherds were preserved using PBMA or another organic polymer. That is why we lose the ability not only to interpret and compare LOI-550 data correctly, but also to determine the original carbon content, both organic and inorganic. It should also be noted that the total carbon content in all samples is lower than LOI-550. Therefore, although the carbon in PBMA makes up about $68 \%$, not the whole amount of LOI-550 can be associated with PBMA burnout. A great difference between the quantities of TC and LOI550 indicates that there also was loss of the structural (hydrated and hydroxylic) water from the ceramic matrix. The reduction in ceramic potsherd weight after its heating at $1000^{\circ} \mathrm{C}$ can be associated with the release of $\mathrm{CO}_{2}$ during the decomposition of carbonates (calcite, dolomite) and the loss of structural water from the crystalline lattice of clay minerals if the ceramics was low-fired or partial rehydroxylation of clay minerals occurred due to the effect of ambient humidity [27, 28]. The LOI1000 values in all the potsherds are minor (0.67$1.07 \%$ ) (Fig. 6). As the data of elemental and phase composition studies suggest, the amounts of calcium and magnesium in the potsherds are small, therefore the LOI-1000 data are more related to the loss of the residual structural water from clay minerals. In addition, when interpreting LOI-1000 data, it should be taken into account that the potsherds were most often fired in the re- ducing or mixed (reducing-oxidising) gaseous environments. Meanwhile, the LOI-1000 content is determined in the air (in an oxidising gas medium) and some elements (especially Fe and Mn) are oxidised by air oxygen. In this case the loss of mass occurring during the dehydroxylation of the minerals is compensated by the increase in mass due to the oxidative processes. This is particularly important to be considered when ceramics with a high $\mathrm{Fe}$ content are studied.

The general elemental composition of archaeological ceramics reflects the chemical composition of the ceramic product and is often used by archaeologists to determine the provenance of ceramics. Interpreting these data and especially looking for links between ceramics and its raw materials, i.e. sources of clay and additives, the following factors should be considered [29-31]:

1. The chemical composition of the clay may be changed after clay has been refined prior to clay paste preparation.

2. The water used to prepare the clay paste may contain dissolved $\mathrm{Na}, \mathrm{K}, \mathrm{Ca}, \mathrm{Mg}$ and $\mathrm{Fe}$ compounds.

3. The composition of the final product depends on the clay/additives ratio in the clay paste.

4. The composition of ceramics may change during firing upon contact with ash or penetration of volatile salts.

5. The composition of ceramics changes during its use, and these changes depend on the materials it contacts.

6. Quite significant changes in the composition of the ceramics are possible through interaction with the burial environment, in which some chemical elements can be washed away while some others can be deposited (taken up or absorbed).

Table 2 shows the total elemental composition data (in weight \%) of archaeological ceramics samples obtained by the X-ray fluorescence spectroscopy (WDXRF) method. These data provide information on the raw materials (clay and additives) used for the production of ceramics. Since there was no possibility to investigate (determine the elemental composition) possible sources of clay and soil in the places where the fragments of ceramics were found, it is not possible to determine precisely which clay was used to make ceramics and what changes in its composition occurred after burial. Therefore, it is necessary to use the data provided by other authors on the 
composition of Lithuanian clays, the composition of possible additives, traditions of ceramic production $[1,4,32,36$.

In Lithuania, illitic clays are predominant and the major clay minerals in them are illite (hydromica) - $\left(\mathrm{K}, \mathrm{H}_{3} \mathrm{O}\right)(\mathrm{Al}, \mathrm{Mg}, \mathrm{Fe})_{2}(\mathrm{Si}, \mathrm{Al})_{4} \mathrm{O}_{10}\left[(\mathrm{OH})_{2}\right.$, $\left.\left(\mathrm{H}_{2} \mathrm{O}\right)\right]$. There may also be minor amounts of other clay minerals: kaolinite $\mathrm{Al}_{2} \mathrm{Si}_{2} \mathrm{O}_{5}(\mathrm{OH})_{4}$, chlorite $(\mathrm{Mg}, \mathrm{Fe})_{3}(\mathrm{Si}, \mathrm{Al})_{4} \mathrm{O}_{10}(\mathrm{OH})_{2} \cdot(\mathrm{Mg}, \mathrm{Fe})_{3}(\mathrm{OH})_{6}$, montmorillonite $(\mathrm{Na}, \mathrm{Ca})_{0.33}(\mathrm{Al}, \mathrm{Mg})_{2}\left(\mathrm{Si}_{4} \mathrm{O}_{10}\right)(\mathrm{OH})_{2}$. $n \mathrm{H}_{2} \mathrm{O}$ and others. The content of aluminium, silicon, potassium, magnesium and even iron in the raw material depends on the quantity of these minerals in clay. In addition to clay minerals, the clay may contain a variety of natural impurities: quartz $\mathrm{SiO}_{2}$; mi- cas - biotite $\mathrm{K}(\mathrm{Mg}, \mathrm{Fe})_{3}(\mathrm{OH}, \mathrm{F})_{2}\left[\mathrm{AlSi}_{3} \mathrm{O}_{10}\right]$ and muscovite $\mathrm{KAl}(\mathrm{OH})_{2}\left[\mathrm{AlSi}_{3} \mathrm{O}_{10}\right]$; feldspars - orthoclase $\mathrm{KAlSi}_{3} \mathrm{O}_{8}$, albite $\mathrm{NaAlSi}_{3} \mathrm{O}_{8}$, anorthite $\mathrm{CaAl}_{2} \mathrm{Si}_{2} \mathrm{O}_{8}$; carbonate minerals - calcite $\mathrm{CaCO}_{3}$, dolomite $\mathrm{CaMg}\left(\mathrm{CO}_{3}\right)_{2}$, etc.

Silicon is the predominant chemical element found in the studied potsherds along with oxygen. Although silicon is a constituent of many minerals (both clay minerals and others), high silicon content indicates that lean (rich in quartz impurities) clay was used to produce ceramics, or it was tempered with minerals, dominated by quartz. It is known that crushed stone was commonly used as a temper in the 1st millennium AD in Lithuania. Various types of stones were used, often fine-grained granite, which

Table 2. Total elemental composition of the archaeological sherds, in weight $\%$

\begin{tabular}{|c|c|c|c|c|c|c|c|c|c|c|}
\hline \multirow{4}{*}{ Element } & \multicolumn{10}{|c|}{ Sites } \\
\hline & \multicolumn{3}{|c|}{ Užpelkiai } & \multicolumn{3}{|c|}{ Obstainiai-Vilkyškiai } & \multicolumn{3}{|c|}{ Lazdininkai-Kalnalaukis } & \multirow[t]{2}{*}{ Imbarè } \\
\hline & \multicolumn{9}{|c|}{ Investigated sample ID } & \\
\hline & U1 & U2 & U3 & V1 & V2-1 & V2-2 & L1 & L2-1 & L2-2 & I1 \\
\hline Si & 23.5 & 23.1 & 28.7 & 23.1 & 23.9 & 20.1 & 27.4 & 21.5 & 21.2 & 21.4 \\
\hline Al & 14.0 & 16.0 & 6.88 & 7.25 & 8.04 & 15.5 & 5.65 & 15.4 & 16.8 & 7.36 \\
\hline $\mathrm{Fe}$ & 4.10 & 3.79 & 4.95 & 6.66 & 7.24 & 4.73 & 9.23 & 4.37 & 4.60 & 6.16 \\
\hline $\mathrm{Ca}$ & 0.344 & 0.313 & 0.720 & 1.12 & 0.716 & 0.864 & 0.316 & 0.498 & 0.633 & 0.699 \\
\hline Mg & 2.90 & 2.71 & 0.667 & 0.695 & 0.794 & 3.33 & 0.538 & 3.43 & 4.60 & 0.682 \\
\hline $\mathrm{Na}$ & 1.50 & 1.55 & 1.44 & 0.600 & 0.550 & 0.890 & 1.11 & 1.24 & 0.901 & 0.971 \\
\hline$K$ & 3.52 & 3.79 & 2.26 & 3.42 & 2.72 & 3.24 & 2.80 & 3.25 & 3.64 & 2.68 \\
\hline $\mathrm{Ti}$ & 0.649 & 0.527 & 0.301 & 0.388 & 0.439 & 0.631 & 0.324 & 0.616 & 0.628 & 0.453 \\
\hline $\mathbf{P}$ & 0.262 & 0.116 & 0.065 & 1.62 & 0.924 & 2.34 & 0.095 & 0.301 & 0.336 & 0.570 \\
\hline$S$ & 0.021 & 0.041 & 0.008 & 0.012 & 0.009 & 0.010 & 0.023 & 0.012 & 0.030 & 0.018 \\
\hline $\mathbf{N i}$ & 0.012 & 0.006 & 0.005 & 0.004 & 0.007 & - & 0.006 & 0.012 & 0.011 & 0.006 \\
\hline Co & 0.018 & 0.009 & - & - & - & 0.013 & - & - & 0.015 & - \\
\hline $\mathrm{Cu}$ & - & 0.051 & 0.003 & 0.002 & 0.003 & 0.006 & 0.001 & 0.010 & 0.011 & 0.003 \\
\hline $\mathrm{Zn}$ & 0.026 & 0.011 & 0.007 & 0.037 & 0.018 & 0.060 & 0.006 & 0.016 & 0.063 & 0.021 \\
\hline Mn & 0.017 & 0.047 & 0.076 & 0.098 & 0.054 & 0.050 & 0.090 & 0.024 & 0.031 & 0.085 \\
\hline $\mathrm{Zr}$ & 0.029 & 0.025 & 0.017 & 0.012 & 0.015 & 0.019 & 0.011 & 0.025 & 0.023 & 0.023 \\
\hline $\mathbf{R b}$ & 0.026 & 0.030 & 0.012 & 0.024 & 0.022 & 0.021 & 0.023 & 0.025 & 0.028 & 0.022 \\
\hline Sr & 0.007 & 0.007 & 0.009 & 0.024 & 0.015 & 0.024 & 0.005 & 0.007 & 0.009 & 0.011 \\
\hline $\mathrm{Cr}$ & 0.014 & 0.015 & 0.007 & 0.009 & 0.009 & 0.012 & 0.006 & 0.007 & 0.016 & 0.005 \\
\hline $\mathbf{Y}$ & 0.008 & 0.008 & 0.005 & 0.005 & 0.004 & - & 0.004 & 0.007 & - & 0.005 \\
\hline $\mathrm{Ba}$ & 0.048 & - & 0.038 & 0.078 & 0.095 & 0.172 & 0.028 & 0.056 & 0.048 & 0.062 \\
\hline $\mathbf{P b}$ & - & 0.015 & - & - & - & - & - & - & - & 0.002 \\
\hline $\mathrm{Cl}$ & 0.013 & 0.021 & 0.009 & 0.010 & 0.009 & - & 0.010 & 0.007 & 0.014 & 0.008 \\
\hline 0 & 45.2 & 46.0 & 48.8 & 50.9 & 50.6 & 45.8 & 47.2 & 44.5 & 46.4 & 47.7 \\
\hline$C$ & 3.78 & 1.81 & 3.34 & 1.22 & 0.988 & 2.09 & 3.14 & 2.38 & - & 3.84 \\
\hline Sum & 100 & 97.6 & 98.3 & 97.4 & 97.2 & 100 & 98.1 & 97.6 & 100 & 98.8 \\
\hline
\end{tabular}


was crushed to pieces of 1 to $3 \mathrm{~mm}$ in diameter or larger ones [37]. Granite was used for practical reasons. First of all, its high accessibility, because $60 \%$ of all boulders found in Lithuania consist of various types of granite [38]. Secondly, the most common type of granite - amphibole-biotite granite (rapakivis) - is easily crushed due to its porphyritic structure [39], so it seems very likely that ancient potters gave him a preference for non-plastic additives for ceramics production. Although the chemical composition of different types of granite varies, $\mathrm{SiO}_{2}$ is the dominant component (about 72\%) in it [40].

Aluminum, along with silicon, is not only a component of clay minerals (natural aluminosilicates), but it is also a constituent of other minerals (e.g. micas, feldspars) that can be used as a temper. However, high $\mathrm{Al}$ content is most often associated with clay mineral abundance, i.e. the so-called 'fat' clay, and in the case of the ceramics under our investigation - perhaps with a higher amount of kaolinite in clay paste.

The highest silicon content was found in sample U3 (Užpelkiai, a potsherd of a miniature cup), while the aluminum content in it was one of the lowest. As can be seen in the cross-section of this specimen (Fig. 3), the potsherd contains a large number of rock debris that had been used as a temper, which determined such peculiarities of the composition. The smallest amount of silicon, but the highest quantity of aluminum is found in sample V2-2 (Opstainiai-Vilkyškiai, a household pot with a smooth surface). A different elemental composition of fragments V2-2 and V2-1 of the same smooth ceramics could mean that the small potsherds found in the same pit belong to different pots. A high iron content (3.8-9.2) indicates that clays rich in iron were used for the production of the investigated potsherds. The highest iron content was found in sample L1 (Lazdininkai-Kalnalaukis, a household pot) -9.23 and it is even higher than that of aluminum (5.65). This sample also contains one of the highest amounts of silicon (27.4). It can be assumed that in the production of this pottery, along with clay and rock debris bog iron ore could be added to the clay paste. This is partly confirmed by the archaeological context. The Lazdininkai-Kalnalaukis burial ground and settlement located in the highlands, at the foot of the eastern hillside of the burial ground, is damp, after rain, while the southern side is a springy area. Iron was produced in the settlement, the parts of an iron smelting furnace were found, while the potsherd was found in a pit, in a cultural layer, probably in a sunken building [41]. Therefore, it is probable that bog iron ore or residues of iron smelting could be used to prepare clay paste. The amounts of calcium, magnesium, sodium and potassium in ceramics reflect the chemical and partly mineralogical composition of the raw materials used for production. The pottery fragments, which belong to both miniature cups (U1, U2) and household pots (V2-2, L1 and L2-2), are dominated by potassium and magnesium. The maximum magnesium and potassium contents were determined in sample L2-2 and sample U2, respectively. Samples U3, L1, and I1 are dominated by potassium and sodium, and this fact can be attributed to the chemical and mineral composition of the temper (the largest amounts of temper grains are observed in the cross-section of these potsherds) (Fig. 3).

When investigating the prevalence of trace elements in the samples of archaeological ceramics, it has been found that sample V2-2 has the highest barium content, but no lead, yttrium or nickel was detected. Lead, cobalt, yttrium, nickel and copper are far from being the chemical elements found in all samples. A higher content of lead was found only in sample U2, while a higher content of cobalt in U1, V2-2 and L2-2, and that of nickel in samples U2, L2-1 and L2-2.

Oxygen dominates all non-metals in all the samples. Although the amounts of other non-metals are small, they differ considerably, i.e. sulphur and chlorine concentrations are $0.008-0.041 \%$ and $0-0.021 \%$, respectively. The highest sulphur and chlorine levels were found in sample U2. Also, this sample possesses maximum amounts of other trace elements, such as $\mathrm{Cu}, \mathrm{Rb}$ and $\mathrm{Pb}$. Phosphorus is another non-metallic and important biogenic element [42, 43]. The amount of phosphorus in archaeological ceramics provides an indication not only of the raw materials used in the production of ceramics and the peculiarities of the production technology, but also highlights the intended use of such ceramics and the impact of the environment in which they were later buried [44, 45]. An abnormally high amount of phosphorus was found in the household potsherds (V2-2 and V1) found in the Opstainiai-Vilkyškiai hillfort foot settlement, probably in a household waste pit. 
The data obtained do not support the view that phosphorus enters the ceramic fragments from the soil in which the deceased was buried or the soil containing the bone [44]. However, these data do not contradict the opinion that phosphorus may have entered the potsherds from various human wastes containing phosphorus, as well as from fertilizers (cattle and poultry manure) [46].

Phosphorus (in the same manner as $\mathrm{Mn}, \mathrm{Ba}$, $\mathrm{Mg}, \mathrm{Zn}$ ) could enter the walls of household pots during cooking, because it is abundant in some food products (fish, bones, nuts, seeds, etc.) [45]. Amounts of $\mathrm{Sn}, \mathrm{Pb}, \mathrm{Zn}$ and $\mathrm{Cu}$ larger than usual in the archaeological environment could be associated with human activity - not ferrous metal smelting and/or processing [47, 48]. Summarizing the data of the elemental composition of archaeological ceramics, it can be stated that the potsherds found in the same area have different chemical composition and, therefore, cannot be parts of the same vessel. The potsherds (U1 and U2) found in the Užpelkiai burial ground have the closest chemical compositions, although they are from different miniature cups. Therefore, it is likely that they were made from a clay paste of a very close chemical composition.

The local elemental composition of the ceramic matrices was determined in the cross-section of the sample by the EDX method. The results of this study, although not as precise as WDXRF, more accurately depict the chemical composition of the clay used for the production of ceramics, since EDX allows analysing the matrix sites free of large grains of the temper. Significant differences in the chemical composition of the ceramic matrix of different samples may be related to different clay sources. It is also possible to determine the uniformity of the distribution of the chemical elements in the ceramic matrix and, if necessary, the chemical composition of the individual grains of the temper. In cases where the inert temper (sand, crushed granite, etc.) is used for the production of ceramics certain essential chemical processes occur in the ceramic matrix. Therefore, the results of EDX analyses are very useful in determining the chemical changes that occurred in ceramics after its firing, i.e. using and burying ceramic artefacts.

Comparison of the elemental composition of the ceramic matrices of all the samples analysed reveals their similarities and differences. The ceram- ics found in the Imbare hillfort settlement stands out against other samples of the ceramics investigated as its matrix contains the highest amounts of $\mathrm{P}, \mathrm{Mn}$ and $\mathrm{Ba}$, its amounts of $\mathrm{Ca}$ and $\mathrm{Na}$ are also among the highest ones, while the quantities of $\mathrm{K}$, $\mathrm{Mg}$ and $\mathrm{Ti}$ are the lowest, and the quantities of $\mathrm{Si}$, $\mathrm{Al}$ and $\mathrm{Fe}$ are among the smallest ones.

In the samples analysed, the amounts of the main constituents of the clay minerals - $\mathrm{Al}$ and $\mathrm{Si}$ - differ only slightly. The amount of aluminum correlates well with LOI-1000, which indicates that all samples of the studied ceramics were fired in a relatively similar temperature range. The minimum amount of aluminum is determined in the matrix of sample L1. The chemical composition of this sample is also distinguished by the fact that its ceramic matrices have a high iron content which even exceeds the aluminum content. Also, a relatively high amount of manganese has been determined in this matrix.

Zinc and barium are rarely found in clay pottery. Ceramic matrices of samples do not all have these two chemical elements. Zinc was not detected in I1, L1, L2-1, L2-2 and U3, while its highest quantity was detected in the matrices of sample V1. Meanwhile, relatively large amounts of barium were determined only in the matrices of samples I1, V1, V2-1 and V2-2. In almost all of these cases, the barium content was higher than its abundance in Earth's crust (0.04\%) [49]. Since barium was found only in household ceramics, therefore it can be stated that the barium content depends on the specific functions of the ceramics, i.e. can be associated with cooking, especially grain [50]. This would explain the fact that barium was not found in the household pot ceramic matrix L1, as this vessel could be used to store food rather than to cook food. The data presented in Table 3 suggest that the barium content correlates fairly well with those of calcium and phosphorus. Since barium accumulates in bones, it can be assumed that bone ash could be used as a temper in the manufacture of ceramics [51]. More detailed research is needed to confirm or deny these assumptions.

When investigating the archaeological ceramic artefacts from the Užpelkiai burial ground it was found that the compositions of the ceramic matrices of samples U1, U2 and U3 are similar and that they differ from the other samples by the highest amounts of $\mathrm{Na}$ and $\mathrm{K}$ and one of the smallest 
Table 3. Average elemental composition of the ceramic matrix in the cross-section of archaeological sherds, in weight $\%$

\begin{tabular}{c|c|c|c|c|c|c|c|c|cc}
\hline \multirow{2}{*}{ Element } & \multicolumn{10}{c}{ Sample ID } \\
\cline { 2 - 12 } & U1 & U2 & U3 & V1 & V2-1 & V2-2 & L1 & L2-1 & L2-2 & I1 \\
\hline Si & 25.5 & 25.2 & 24.8 & 21.3 & 23.3 & 21.5 & 23.7 & 24.8 & 25.5 & 22.6 \\
\hline Al & 8.70 & 9.79 & 9.18 & 9.43 & 10.2 & 9.89 & 8.55 & 9.16 & 9.43 & 8.76 \\
\hline Fe & 6.55 & 6.70 & 6.45 & 7.17 & 7.02 & 7.21 & 10.9 & 7.19 & 6.25 & 6.66 \\
\hline Ca & 0.57 & 0.37 & 0.64 & 1.89 & 0.79 & 1.19 & 0.54 & 0.68 & 0.56 & 1.42 \\
\hline Mg & 1.52 & 1.51 & 1.59 & 1.32 & 1.37 & 1.54 & 1.33 & 1.71 & 1.80 & 0.92 \\
\hline $\mathbf{N a}$ & 0.50 & 0.36 & 0.51 & 0.31 & 0.27 & 0.26 & 0.39 & 0.47 & 0.33 & 0.46 \\
\hline $\mathbf{K}$ & 3.99 & 3.97 & 3.89 & 3.57 & 3.31 & 3.83 & 3.11 & 4.00 & 4.10 & 2.74 \\
\hline Ti & 0.62 & 0.59 & 0.63 & 0.58 & 0.63 & 0.61 & 0.54 & 0.56 & 0.55 & 0.52 \\
\hline $\mathbf{P}$ & 0.26 & 0.13 & 0.18 & 2.51 & 1.02 & 1.98 & 0.29 & 0.13 & 0.20 & 2.77 \\
\hline Zn & 0.09 & 0.08 & 0.00 & 0.11 & 0.05 & 0.09 & 0.00 & 0.00 & 0.00 & 0.00 \\
\hline Mn & 0.10 & 0.17 & 0.15 & 0.08 & 0.10 & 0.10 & 0.24 & 0.09 & 0.09 & 0.40 \\
\hline Ba & 0.00 & 0.00 & 0.00 & 0.10 & 0.03 & 0.17 & 0.00 & 0.00 & 0.00 & 0.19 \\
\hline $\mathbf{O}$ & 51.5 & 50.9 & 48.8 & 51.7 & 51.9 & 51.7 & 50.2 & 51.1 & 51.1 & 52.5 \\
\hline
\end{tabular}

amounts of Fe and P. The ceramic matrices of samples U1 and U3 have the closest chemical compositions, so it can be assumed that the ceramics could have been made from the clay taken from the same source. So, although all the Užpelkiai miniature cups are relatively contemporaneous, their clay paste composition and production technologies diverge.

The compositions of the ceramic matrices of samples V1, V2-1 and V2-2 (Opstainiai-Vilkyškiai, potsherds of household pots) differ as the amounts of chemical elements forming clay minerals vary. Clays from different locations are likely to be used to produce the ceramics.

The elemental compositions of the ceramic matrices of samples L2-1 and L2-2 are quite close, as the amounts of aluminium and silicon differ very little. In addition, the highest levels of potassium and magnesium were determined, while the amounts of calcium were the lowest ones. Samples L2-1 and L2-2 are likely to be parts of the same miniature cup found in the human cremation burial. One can doubt only somewhat higher differences between the $\mathrm{Na}$ and $\mathrm{Fe}$ quantities.

The experimental data obtained confirm the assumption that the investigated potsherds were made of rich in iron but poor in carbonates alluvial clays found near the ground surface [52]. Their carbonate content is much less than that of deep-clay, because frost and water break down and wash off carbonate minerals. Also, these clays may contain many organic materials and even plant residues [33, 48].

\section{CONCLUSIONS}

Archaeological ceramics are a complex subject of research. Organic polymers are used for their reinforcement and preservation, therefore neither the original amount of organic carbon nor the loss on ignition can be accurately determined, and the performance of structure tests is hindered. In addition, it was not possible to investigate possible sources of raw materials or soil in which the ceramic vessels had been buried. This should be taken into account in future studies.

The analysis of the available samples has shown that the differences between the elemental composition of the samples and the manufacturing techniques of the ceramics are more related to the area, i.e. the customs of the community that lived there and the technological skills of ceramics potters rather than with the intended use of ceramics. Pottery was made from local illitic clays that occur near the ground surface. When preparing the clay paste, crushed granite was used as a temper. The amount of the temper and the size of grain vary, but in miniature cups from some sites the temper quantity is reduced and its grains are smaller. Meanwhile, producing household pottery, 
a large amount of temper was added and its grains were large. The clay paste also contained many organic materials, but their nature is unclear. Organic materials could enter the clay paste either with clay or as an additive to improve the clay paste properties. The studied ceramics were usually fired under reducing conditions, sometimes under reducing-oxidising and only in rare cases - under oxidising conditions. The household pot and miniature cups were fired at not sufficiently high temperatures and kept at a maximum temperature for a too short time, therefore not the whole structurally bond water was removed from the clay minerals and the carbon was not burnt out completely. It seems likely that all the investigated ceramics were fired in the open fire, except for the ceramics of sample U2, which had also been made from different clay paste. Our investigation did not confirm an assumption that the miniature cups were made of clay paste of different composition and were 'worse' fired.

\section{ACKNOWLEDGEMENTS}

This work was supported by the Research Council of Lithuania (Grant number LIP-098/2016).

Received 9 April 2019 Accepted 23 April 2019

\section{References}

1. A. Krapukaityte, Ph. D. Thesis, Vilnius University (2009).

2. A. Kareiva, J. Kiuberis, A. Merkevičius, Archaeologia Lituana, 12, 25 (2001).

3. J. Kiuberis, A. Merkevičius, R. Juškènas, A. Kareiva, Mater. Sci., 10, 334 (2004).

4. S. Tautkus, A. Beganskienè, A. Žarkov, A. Merkevičius, A. Kareiva, in: A. Merkevičius (ed.), Metodai Lietuvos archeologijoje. Mokslas ir technologijos praeičiai pažinti (Methods in Archaeology. Science and Technologies to Cognize the Past), p. 137, Vilniaus universiteto leidykla, Vilnius (2013) [in Lithuanian].

5. A. Bliujienè, Užpelkiu plokštinio kapinyno (Kretingos r.) 1993 metu archeologiniu tyrinèjimy ataskaita (Report on the 1993 Archaeological Research of Užpelkiai Laminar Cemetery (Kretinga District), unpublished excavation report, archive, corpus 1, file 2177, Lithuanian Institute of History (1993) [in Lithuanian].

6. A. Bliujienė, R. Bračiulienè, Užpelkiu kapinynas Lietuvos pajūrio ir Baltijos jūros regiono kultūriniuose kontekstuose (Užpelkiai Cemetery in the Cultural Contexts of Lithuanian Seacoast and Baltic Sea Regions), Dailès akademijos leidykla, Vilnius (2018) [in press, in Lithuanian].

7. A. Bliujienè, Užpelkiu plokštinio kapinyno Kretingos apskrityje, Rūdaičiu valsčiuje, 1994 metų tyrinejimu ataskaita (Report on the 1994 Research of Užpelkiai Laminar Cemetery in Rūdaičiai, Kretinga District), unpublished excavation report, archive, corpus, 1, file 2341, Lithuanian Institute of History (1994) [in Lithuanian].

8. D. Balsas, R. Jarockis, G. Zabiela, in: A. Bliujienè (ed.), Klaipedos (Memel) kraštas: nuo ištaku iki XVII amžiaus (The Klaipeda (Memel) Region: From Origins to the 17 th Century), p. 243, Dailès akademijos leidykla, Klaipeda (2018) [in Lithuanian].

9. R. Jarockis, Opstainiu (Vilkyškiu) piliakalnio su gyvenviete (23812) Pagégiu sav. $2010 \mathrm{~m}$. archeologiniai žvalgymai (2010 Archaeological Explorations of Opstainiai (Vilkiškiai) Hillfort with a Settlement (23812) in Pagègiai Municipality, unpublished excavation report, archive, Lithuanian Institute of History (2010) [in Lithuanian].

10. R. Jarockis, Archaeologia Baltica, 17, 136 (2012).

11. A. Bliujienè, I. Matulaitienè, A. Garbaras, et al., Praehist. Z., 93(1), 144 (2018).

12. V. Žulkus, Acta Historica Universitatis Klaipedensis, VI (1997).

13. D. Butkus, Lazdininku (Kalnalaukio) plokštinio kapinyno (Darbeny apyl. Kretingos r. 1993 mety archeologiniu kasinejimy ataskaita (Report on the 1994 Research of Lazdininkai (Kalnalaukis) Laminar Cemetery in Darbenai, Kretinga District), unpublished excavation report, archive, corpus, 1, file 2568, Lithuanian Institute of History (1993) [in Lithuanian].

14. S. Patkauskas, Lazdininku senkapio (Kretingos r.) archeologiniu tyrimu ataskaita, 1-3 dalis (Report on the Archaeological Research of Lazdininkai Burial-Ground (Kretinga District), Parts 1-3, unpublished excavation report, archive, corpus, 1 , file 453, Lithuanian Institute of History (1976) [in Lithuanian].

15. Z. Baubonis, G. Zabiela, Lietuvos piliakalniai. Atlasas (Atlas of Lithuanian Hillforts), Vols. I-III, Vilnius (2005) [in Lithuanian].

16. O. Opuchovic, A. Kareiva, Ceram. Int., 41, 4504 (2015).

17. V. Valanciene, R. Siauciunas, J. Baltusnikaite, J. Eur. Ceram. Soc., 30, 1609 (2010).

18. J. Buxeda i Garrigós, R. Jones, V. Kilikoglou, et al., Archaeometry, 45(2), 263 (2003).

19. M. Maggetti, Ch. Neururer, D. Ramseyer, Appl. Clay Sci., 53(3), 500 (2011).

20. M. H. Jeong, D. H. Lee, J. W. Bae, Int. J. Hydrog. Energy, 40, 2613 (2015).

21. A. De Bonis, G. Cultrone, C. Grifa, et al., Ceram. Int., 43, 8065 (2017). 
22. R. Thér, Archaeometry, 56, 78 (2014).

23. D. Kumar, A. J. Neelam, J. Chem. Pharm. Res., 8(10), 86 (2016).

24. P. C. Beuria, S. K. Biswal, B. K. Mishra, G. G. Roy, Int. J. Min. Sci. Technol., 27, 1031 (2017).

25. J. Molera, T. Pradell, M. Vendrell-Saz, Appl. Clay Sci., 13, 187 (1998).

26. C. Klein, B. Dutrow, Manual of Mineral Science, 23rd edn., p. 675, John Wiley and Sons, Inc., Hoboken, NJ (2007).

27. A. Miras, E. Galán, I. González, A. Romero-Baena, D. Martin, Appl. Clay Sci., 161, 176 (2018).

28. R. E. Grim, W. F. Bradley, Am. Mineral., 33, 50 (1948).

29. T. D. Price, J. H. Burton, An Introduction to Archaeological Chemistry, p. 233, Springer-Verlag, New York (2011).

30. S. De la Vega, M. Jiménez-Reyes, D. Tenorio, et al., Microchem. J., 114, 59 (2014).

31. S. Karacic, M. Jameson, A. B. Weil, J. Archaeol. Sci. Rep., 9, 599 (2016).

32. G. Vaitkevičius, in: G. Vaitkevičius (ed.), Miestu praeitis (The Past of Cities), Vol. 1, p. 175, Vilnius (2004) [in Lithuanian].

33. A. Griežienè (ed.), Tradicinès keramikos dirbiniu formos, dekoras, gamyba ir išdegimas (Remiantis archeologine ir etnografine medžiaga) (Shaping, Decoration, Manufacturing and Baking of Traditional Ceramic Products (Based on the Archaeologic and Ethnographic Material), S. Jokužio leidyklaspaustuve, Vilnius (2011) [in Lithuanian].

34. V. Raidla, K. Kirsimäe, L. Bityukova, A. Jõeleht, A. Shogenova, S. Šliaupa, Geol. Q., 50(4), 395 (2006).

35. G. Juozapavičius, Ataskaita už mokslini tiriamaji darbq ,Molio telkiniu tyrimo ir išteklių klasifikavimo rekomendacijos" (Report on Scientific Research 'Recommendations for Investigation of Clay Deposits and Classification of Resources', Magma, Vilnius (1994) [in Lithuanian].

36. A. Grigelis, V. Kadūnas, Lietuvos geologija (Geology of Lithuania), Mokslo ir enciklopedijų leidykla, Vilnius (1994) [in Lithuanian].

37. R. Vengalis, Lietuvos archeologija, 32, 105 (2007) [in Lithuanian].

38. A. Linčius, Lietuvos geologijos paminklai ir draustiniai (Geological Monuments and Reserves of Lithuania), Mokslo ir enciklopedijų leidykla, Vilnius (1994) [in Lithuanian].

39. V. Baltrūnas, Acta humanitarica universitatis Saulensis, 6, 14 (2008).
40. H. Blatt, R. J. Tracy, Petrology. Igneous, Sedimentary, and Metamorphic, 2nd edn., p. 66, W. H. Freeman, NY (1996).

41. J. Navasaitis, Lietuviška geležis (Lithuanian Iron), Technologija, Kaunas (2004) [in Lithuanian].

42. A. Simniškyte, in: A. Merkevičius (ed.), Metodai Lietuvos archeologijoje. Mokslas ir technologijos praeičiai pažinti (Methods in Archaeology. Science and Technologies to Cognize the Past), p. 305, Vilniaus universiteto leidykla, Vilnius (2013) [in Lithuanian].

43. A. Sarris, M. L. Galaty, R. W. Yerkes, et al., J. Archaeol. Sci., 31, 927 (2004).

44. L. Maritan, I. Angelini, G. Artioli, C. Mazzoli, M. Saracino, J. Cult. Herit., 10, 144 (2009).

45. M. L. Costa, D. C. Kern, A. H. E. Pinto, J. R. T. Souza, Acta Amaz., 34(3), 375 (2004).

46. M. G. Stamatakis, N. K. Koukouzas, Sediment. Geol., 139, 33 (2001).

47. C. Orton, P. Tyers, A. Vince, Pottery in Archaeology, Cambridge University Press, Cambridge (1993).

48. J. Poškienè, in: G. Vaitkevičius (ed.), Miestu praeitis (The Past of Cities), Vol. 1, p. 125, Vilnius (2004) [in Lithuanian].

49. K. B. Krauskopf, Introduction to Geochemistry, 2nd edn., p. 617, McGraw-Hill, New York (1979).

50. G. F. Nordberg, B. A. Fowler, M. Nordberg, et al. (ed.), Handbook on the Toxicology of Metals, 3rd edn., p. 409, Elsevier, London (2007).

51. O. Stilborg, Eur. J. Archaeol., 4, 398 (2001).

52. J. M. Skibo, Understanding Pottery Function, Springer, New York (2013).

Raimondas Giraitis, Audronė Bliujienė, Aušra Selskienė, Vidas Pakštas

\section{I-OJO TŪKSTANTMEČIO MINIATIŪRINIŲ PUODELIŲ IR BUITYJE NAUDOTỤ PUODŲ ŠUKIŲ TYRIMAI: VAKARŲ LIETUVOS KERAMIKOS TYRIMO ATVEJIS}

Santrauka

Straipsnyje pateikiami keturi skirtingų Vakarų Lietuvos vietovių I-ojo tūkstantmečio po Kristaus lipdytų miniatiūrinių puodelių, dedamų $\mathfrak{i}$ kapus, ir buityje naudotų indų struktūros bei elementinių sudèties tyrimų rezultatai. Jie atspindi keramikos gamybai naudotų vietinių žaliavų cheminę sudètí, o sudèties ịvairovè rodo skirtingas molio radimvietes, taip pat liesiklių panaudojimo ir degimo technologijos ypatumus. 